\title{
INTERACTIVE METADISCOURSE AND INTERACTIONAL METADISCOURSE CATEGORIES OF STUDENTS' INTERNATIONAL PROGRAM SCHOOL BASED ON GENDER
}

\author{
Suhono, Haikal \\ Institut Agama Islam Ma'arif NU Metro, Indonesia \\ (suhono120708@gmail.com; haikaliaimnu1@gmail.com)
}

Received: $11^{\text {th }}$ March 2018; Revised: $27^{\text {th }}$ May 2018; Accepted: $28^{\text {th }}$ June 2018

\section{ABSTRACT}

The aim of this study was to develop further analyzing of metadiscourse categories in second language learners of International Program School of Muhammadiyah University Surakarta. Specifically, the researchers explored metadiscourse categories (interactive and Interactional) of students' writing result at International Program of Muhammadiyah University Surakarta, the differences of metadiscourse categories with regard to gender (males and female) and factor affected metadiscourse in male and female. The researcher employed Hyland's metadiscourse model in analyzing students' written form which consis of 10 male and 7 female students. The results revealed that interactive metadiscourse consist of frame markers, transition markers, endophoric marker, evidendionals, and code glosses. Meanwhile, the interactional metadiscourse concist of boosters, edges, attitude markers, selfmentions and engagement markers. The researchers also revealed that the category of transition marker was the highest on female students since most female students learn at outside class such as at pondok pesantren.

Key Words: interactive metadiscourse; interactional metadiscourse; metadiscourse; gender

\section{ABSTRAK}

Tujuan penelitian ini adalah untuk mengembangkan analisis lebih lanjut terhadap kategori metadiscourse pada pembelajar bahasa kedua pada Program Internasional Sekolah Universitas Muhammadiyah Surakarta. Secara khusus, para peneliti mengeksplorasi kategori metadiscourse (interactive dan interactional) pada hasil tulisan mahasiswa, perbedaan kategori metadiscourse pada "gender" (laki-laki dan perempuan) dan faktor yang mempengaruhi metadiscourse pada laki laki dan perempuan. Para peneliti menggunakan model Hyland dalam menganalisis metadiscourse pada tulisan mahasiswa yang terdiri dari 10 laki-laki dan 7 perempuan. Penelitian ini menunjukkan bahwa interactive metadiscourse terdiri dari frame markers, transition markers, endhoporic markers, evidendionals, dan code glosses. Sementara itu interactional metadiscourse terdiri dari booseters, edges, attitude markers, self mentions dan engangement markers. Studi ini juga mengungkapkan bahwa penanda transition marker adalah yang tertinggi pada siswa perempuan karena kebanyakan para siswa perempuan belajar di luar kelas seperti di pondok pesantren.

Kata Kunci: interactive metadiscourse; interactional metadiscourse; metadiscourse; gender

How to Cite: Suhono, Haikal.(2018). Interactive Metadiscourse and Interactional Metadiscourse Categories ff Students' International Program School Based on Gender. IJEE (Indonesian Journal of English Education), 5(1), 81-91. doi:10.15408/ijee.v5i1.5505 


\section{INTRODUCTION}

Writing play a crucial role in students' learning process of academic activity, for instance research proposal, writing paragraph, writing summary, etc. On the other hand, writing obtrudes great defiance for novice students' writers. The defiance is even higher when students write in English as a foreign language, as they not only have to suitable themselves to the disciplinary discourse but also to do it in a language whose rhetoric is quite different from their mother tongue. Rustipa (2014) declared that EFL writing is useful to explore students organizing idea, thinking, analyze, and criticize and the second strengthens their learning and thinking. Students, in this case undergraduate students have a lot of projects regarding to writing activity as they are accepted to develop their critical thinking through writing, for instance written composition. Hence, the researcher should be careful to write it and the appropriate linguistics categories need to be used. Written composition involves metadiscourse which associate the appropriate use of linguistic realization (Al-Shujairi, 2016). It represents the writer's effort to lead the reader's perception of a text. Because written composition function as "advertising means" to bring the attention to the reader to read the whole text, metadiscourse is needed to help writers organize their texts, and engage readers. It is the set of linguistic resources that every language has as part of the textual metafunction for linking one part of a text to another. Metadiscourse itself is discourse about discourse or writing about writing. It is a discourse which has a writer-reader interaction in the text. Metadiscourse is self-reflective linguistic expressions referring to the evolving text, to the writer, and to the imagined readers of that text (Hyland, 2004). The concept of metadiscourse is based on a view of writing (and speaking) as a social and communicative engagement, offering a means of understanding the ways people themselves into texts to manage communicative intentions. The researchers used Hyland' theory because it is seen as potentially useful as it effectively characterizes the need of writers to produce good writing and this model based on the research in academic discourse, that makes the model to be more influential and more concrete and also more updated than any other models of metadiscourse. So far, metadiscourse category has been studied in different country background, for instance, Allami and Mirshami (2013) entitled metadiscourse markers in the discussion section Persian and English Master's Theses. 
They found the differences and the similarities in the use of markers in thre categories; native English speakers, native Persian speakers, and non-native English speakers. The result showed that native English writers used more interactive and interactional metadiscourse markers than native Persian and EFL learners. Secondly, Gholami, Tajalli and Shokrpour (2014:2) investigated metadiscourse markers in English Mdical texts and their translations. The result showed that there was a ignificant difference in the amount and types of metadiscourse markers in English Medical texts and their translations. Further the distribution of different types of metadiscourse markers in English Medical texts is not the same as their distribution in their Persian translation. In the scope of metadiscourse category, especially the researchers in Indonesia, studying it in International Program School and related to gender were rarely done by researchers. Hence, the aim of this research is to develop further analysis about metadiscourse category, especially exploring interactive and interactional metadiscourse of student's writing of International Program School at Muhammadiyah University Surakarta and the differences of metadiscourse categories in gender, males and females students.

\section{The Notion of Metadiscourse}

Metadiscourse in interesting filed of investigation which is believed to play an essential role in organizing and producing a written composition. The term of metadiscourse was explored by Harris, in 1959 to offer a way of understanding language in use, presenting a writer's or speaker's attempts to guide a receiver's perception of a text (Ken Hyland, 2005). It refers to the pragmatic use of language to comment reflexively on discourse itself. Metadiscourse shifts the focus of attention from ongoing communication, putting some stretch of discourse in a context or frame designed to influence the meaning and practical conduct of communication. Metadiscourse is a term which describes a range of open class lexical items (words and expressions), each of which has a relatively stable pragmatic role, and whose main function is to enhance communicative efficiency. It has been important in writing instruction for academic purposes, as a way of helping both native and nonnative speakers of English to convey their ideas and engage with their readers effectively. With the growth of discourse analysis as a key tool in understanding language use, the importance of interaction in writing as much as in speech has become ever more obvious, and metadiscourse has 
emerged as a way of bringing these interactional features to prominence. Based on this view, not only do authors produce a text to convey ideation content, i.e. information, but also they want to make certain that what they express is comprehensible and reasonable.

Hyland's model of metadiscourse divided into two main categories: interactive and interactional metadiscourse. Interactive metadiscourse concerns the writer's awareness of his receiver, and his attempts to accommodate his interests and needs, and to make the argument satisfactory for him. In this part there are five sub-categories, those are, transition, frame markers, endophoric markers, evidential and code glosse. The interactional part, on the other hand, concerns the writer's attempts to make his views explicit and to engage the reader by anticipating his objections and responses to the text. The subcategories for interactional part of metadiscourse are hedges, boosters, attitude markers, self-mentions, and engagement markers.

\section{Classification of Metadiscourse}

Hyland's model is based on the research in academic discourse, which makes the model more concrete and more influential. It is also noted by Abdi (2011:5) that Hyland's model is highly preferred in modern metadiscourse studies for being recent, simple, clear and comprehensive. There are two categories of metadiscourse, interactive and interactional.

\section{Interactive Metadiscourse}

Interactive resources allow the writer to help the reader to correctly interpret the text by managing information flow. They are concerned with ways of organising discourse to anticipate readers' knowledge and reflect the writer's assessment of what needs to be made explicit to constrain and guide what can be recovered from the text. It consis of Transition, Frame Markers, Endophoric Markers, Evidential, Code Glosses.

\section{Transition}

logical connectors that express the semantic relation between main clauses or sentences. But, to count as metadiscourse they must perform a role internal to the discourse rather than the outside world, helping the reader interpret links between ideas.10 Examples: In addition, but, thus, and, moreover, furthermore, therefore, on the other hand.

\section{Frame Markers}

Frame markers are used primarily to organize texts for readers. Frame markers are a cover term for a 
variety of linguistic devices and can be further classified into four subtypes according to functions: sequencers, topicalizers, discourselabels, and announcers.13 Examples: Finally, my purpose, firstly, to sum up, in short, return to, in regard to, aim.

\section{Endophoric Markers}

It refers to other parts of the text in order to make additional information available, provide supporting arguments, and thus steer the reader toward a preferred interpretation. For instance

\section{Evidential}

Evidentials refer to information from other. In academic discourse, evidential markers typically take the form of citations or academic attributions

\section{Code Glosses}

It supplies additional information, by rephrasing, explaining or elaborating what has been said, to ensure the reader is able to recover the writer's intended meaning Examples: Called, defined as e.g.

\section{Interactional Metadiscourse}

It focuses on the participants of the interaction and seeks to display the writer's persona and a tenor consistent with the norms of the disciplinary community. Metadiscourse here concerns the writer's efforts to control the level of personality in a text and establish a suitable relationship to his or her data, arguments, and audience, marking the degree of intimacy, the expression of attitude, the communication of commitments, and the extent of reader involvement (Ken Hyland, 2005)

\section{Hedges}

It focuses on the participants of the interaction and seeks to display the writer's persona and a tenor consistent with the norms of the disciplinary community. Metadiscourse here concerns the writer's efforts to control the level of personality in a text and establish a suitable relationship to his or her data, arguments, and audience, marking the degree of intimacy, the expression of attitude, the communication of commitments, and the extent of reader involvement. Abdi (2011:167) gave example it in a sentence: It is possible that the measurement of more than one endpoint of the irritation response would be necessary to adequately assess. 


\section{Boosters}

This category allows the writer to anticipate and preclude alternative, conflicting arguments by expressing certainty instead of doubt. Examples: In fact, definitely, it is clear that, clearly, it shows, indeed.

\section{Attitude markers}

This category expresses the writer's appraisal of propositional information, conveying surprise obligation, agreement, importance, and so on.31 Examples: Unfortunately, surprisingly, I agree, hopefully.

\section{Self Mention}

It refers to the degree of explicit author presence in the text. This can be realized by the use of first person pronouns and the possessive adjectives 'I, me, we, my, our, mine and us'. Other categories that can be used to 'self- mention' are 'the author, the writer, the author's and the writer's'.

\section{Engagement Markers}

It markers explicitly address readers to draw them into the discourse. In other words, it explicitly builds a relationship with the reader. It means when writing, writers should really feel the presence of their readers, pull them along with their arguments, focus their attention, regard them as discourse participants and finally lead them to the right interpretations.

\section{METHOD}

The researches used qualitative research because this study was focusing on the total description rather than breaking it down into variables. The research conducted qualitative research and was descriptive and explorative since it described metadiscourse categories, and the possible cause of the metadiscourse categories commonly appeared in a text. This research focused on content or document analysis. The subject of this research was 17 students that consist of male 10 and female 7 students form an international program school. The researcher used Hyland's metadiscourse model in analyzing students' written form.

\section{FINDING AND DISCUSSION \\ Interactive and Interactional metadiscourse of student's written}

The researcher found the type of interactive and interactional metadiscourse of students' written of international program school of Muhammadiyah University Surakarta. 
The total of interactive metadiscourse was 81 . The types of interactive metadiscourse of students' written form involve transition markers, Frame Markers, and Code Glosses.

Transition markers

The researchers found 52 transition markers which are applied by students international program school in written composition. Below some remarks appeared of transition markers:

Table 1. Transition markers

\begin{tabular}{lll}
\hline No. & Remarks & Total \\
\hline $\mathbf{1}$ & Unfortunately & 6 \\
$\mathbf{2}$ & However & 5 \\
$\mathbf{3}$ & Since & 4 \\
$\mathbf{4}$ & Because & 8 \\
$\mathbf{5}$ & Therefore & 5 \\
$\mathbf{6}$ & Afterward & 7 \\
$\mathbf{7}$ & Either...or.. & 4 \\
$\mathbf{8}$ & So that & 5 \\
$\mathbf{9}$ & Meanwhile & 4 \\
$\mathbf{1 0}$ & Thus & 4 \\
& Total & 52 \\
\hline
\end{tabular}

Frame Markers

Furthermore, the researcher found 18 frame markers in students' written composition. Bellow the analysis result of frame markers:

Table 2. Frame Markers

\begin{tabular}{lll}
\hline No. & Remarks & Total \\
\hline $\mathbf{1}$ & Intents to & 2 \\
$\mathbf{2}$ & Firstly & 4 \\
$\mathbf{3}$ & Attempts to & 2 \\
$\mathbf{4}$ & Aim to & 3 \\
$\mathbf{5}$ & Focus on & 3 \\
$\mathbf{6}$ & Then & 4 \\
& Total & 18 \\
\hline
\end{tabular}

\section{Code Glosses}

The researcher found 11 frame markers in students' written composition. Bellow the analysis result of frame markers.

Table 3. Code Glosses

\begin{tabular}{lll}
\hline No. & Remarks & Total \\
\hline $\mathbf{1}$ & Namely & 2 \\
$\mathbf{2}$ & It means & 5 \\
$\mathbf{3}$ & They are & 4 \\
& Total & 11 \\
\hline
\end{tabular}

Secondly, the types of interactional metadiscourse of students' written form involve hedges, boosters, attitude markers, self mentions, and engagement markers. The total of interactive metadiscourse was 47 .

\section{Hedges}

It allows the writer to present information as an opinion or plausible reasoning rather than thefact the researcher found 13 frame markers in students' written composition. Bellow the analysis result of frame markers.

Table 4. Hedges

\begin{tabular}{lll}
\hline No. & Remarks & Total \\
\hline $\mathbf{1}$ & Almost & 3 \\
$\mathbf{2}$ & Most of & 1 \\
$\mathbf{3}$ & Mostly & 5 \\
$\mathbf{4}$ & Indicates & 2 \\
$\mathbf{5}$ & Better than.. & 2 \\
& Total & 13 \\
\hline
\end{tabular}


Boosters

It allows the writer to anticipate and preclude alternative, conflicting arguments by expressing certainty instead of doubt. The researcher found 4 boosters in written composition.

Table 5. Boosters

\begin{tabular}{lll}
\hline No. & Remarks & Total \\
\hline $\mathbf{1}$ & Show & 4 \\
$\mathbf{2}$ & In fact & 3 \\
$\mathbf{3}$ & Explain that & 2 \\
$\mathbf{4}$ & Reveal & 2 \\
& Total & 11 \\
\hline
\end{tabular}

Attitude Markers

It expresses the writer's appraisal of propositional information, conveying surprise obligation, agreement, importance.

Table 6. Attitude Markers

\begin{tabular}{lll}
\hline No. & Remarks & Total \\
\hline $\mathbf{1}$ & Unfortunately & 2 \\
$\mathbf{2}$ & Appropriately & 4 \\
$\mathbf{3}$ & Directly & 3 \\
& Total & 9 \\
\hline
\end{tabular}

\section{Self-mentions}

It refers to an explicit reference to the author(s). The researcher found 6 self-mention.

Table 7. Self-mentions

\begin{tabular}{lll}
\hline No. & Remarks & Total \\
\hline $\mathbf{1}$ & The researcher & 6 \\
& Total & 6 \\
\hline
\end{tabular}

Engagement Markers

This category explicitly addresses readers to draw them into the discourse by addressing them as participants in an argument with reader pronouns such as you, your, we. It can also be noted by obligation modals such as should, must, have to, etc.

\section{Table 8. Engagement Markers}

\begin{tabular}{lll}
\hline No. & Remarks & Total \\
\hline $\mathbf{1}$ & We & 2 \\
$\mathbf{2}$ & Must & 3 \\
$\mathbf{3}$ & Your & 3 \\
& Total & 8 \\
\hline
\end{tabular}

The differences of metadiscourse categories in gender, males and females students

After conducting the research, the researcher found the differences of metadiscourse categories in male and female students' international program school. The students were aware of the readers' view when reading their writing composition. The researcher found 81 interactive metadiscourse and 47 interactional metadiscourse. To classify the students based on the gender, the researcher classified the Seventeen students of the 2 level groups into males and females. Males consist of 10 students and female consist of 7 students. The following table described the differences in result metadiscourse based on the gender of the students: 
Table 9. Metadiscourse

\begin{tabular}{|c|c|c|c|}
\hline $\begin{array}{l}\mathbf{N} \\
\mathbf{0}\end{array}$ & $\begin{array}{l}\text { Gende } \\
\mathbf{r}\end{array}$ & Metadiscourse Categories & $\begin{array}{l}\text { Tota } \\
1\end{array}$ \\
\hline 1 & $\begin{array}{l}\text { Males } \\
(10)\end{array}$ & \begin{tabular}{cl}
\multicolumn{2}{l}{ Interactive } \\
1. & Transitions \\
2. & Frame Markers \\
3. & Code Glosses \\
& \\
Interactional \\
1. & Hedges \\
2. & Boosters \\
3. & Attitude Markers \\
4. & Self - mention \\
5. & Engagement markers
\end{tabular} & $\begin{array}{l}34 \\
11 \\
7 \\
52 \\
6 \\
8 \\
7 \\
4 \\
4 \\
29\end{array}$ \\
\hline 2 & $\begin{array}{l}\text { Female } \\
\text { (7) }\end{array}$ & $\begin{array}{ll}\text { Interactive } \\
\text { 1. } & \text { Transitions } \\
\text { 2. } & \text { Frame Markers } \\
\text { 3. } & \text { Code Glosses } \\
\text { Interactional } \\
\text { 1. Hedges } \\
\text { 2. } & \text { Boosters } \\
\text { 3. } & \text { Attitude Markers } \\
\text { 4. } & \text { Self - mention } \\
\text { 5. } & \text { Engagement markers }\end{array}$ & $\begin{array}{l}18 \\
7 \\
4 \\
29 \\
7 \\
3 \\
2 \\
2 \\
4 \\
18 \\
\end{array}$ \\
\hline
\end{tabular}

Males Students' International program school

In classifying the student based on gender, especially in male students, the researcher found that interactive metadiscourse was the highest one, 52 words. While interactional metadiscourse consists of 29 words. Bellow the example of male students in using interactional metadiscourse:

1) "The people should be able to construct their competency because it related to how the students can understand what the teachers said"' (Student 2 )
2) "...unfortunately, the researcher don't do their research effectively." (Student 7 )

3) "He focuses on study magister to get a good knowledge" (Student 14)

4) "there are many factors in contribution students' competence, namely learning style preference, strategy and method in learning process"

On the example above is interactive metadiscourse which occurs in male students. It involved transition markers, frame marker, code glasses. Hyland said that transition markers were divided into three types: addition, comparison and consequence. Form the example above, sentence (1) "The people should be able to construct their competency because it related to how the students can understand what the teachers said" included in addition which add elements to an argument. In contrast with addition, comparison of transition makers argument as different. It means that it contrasts the argument. Sentence (2) "...unfortunately, the researcher don't do their research effectively." "unfortunately" here marks different argument between argumentative writing which is a great topic to write and the difficulty of building a good writing. Then, a consequence of transition markers expresses a result. 
Females Students' International program school

In classifying the student based on gender, especially in male students, the researcher found that interactive metadiscourse was the highest one, 29 words. While interactional metadiscourse consists of 18 words, for instance on hedges and bosters:

a. The teachers are expected that the students should be active in learning English;

b. Most of the young women shelter in their neighbour;

c. Because your football team is better than a new team;

d. New candidate president reveals that Indonesian needed a local business.

\section{The Factors of Affecting Metadiscourse in male and female students.}

After conducting the research, the factors affecting metadiscourse between male and female students were habitual students' learning process. It can be proven when the students are mostly from pondok pesantren, especially in female students. It means that female students from pondok pesantren got increment or augmentation learning English. They are always demanded to use the English language when doing communication.

\section{CONCLUSION AND SUGGESTION}

The result revealed that metadiscourse in the interesting field of investiogation which is believed to play an essential role in organizing and producing of written compossition. The essential metadiscourse is when the readers filter their ideas through a concern with how the readers will take them. It is as like chain-link to make coherence of the sentence, for instance finally, firstly, the second, etc and to express logical connections. Furthermore, Interactive metadiscourse consist of frame markers, transition markers, endophoric markers, evidendionals, and code glosses. While interactional metadiscourse consist of boosters, edges, attitude markers, self mentions and engaggement markers. The researcher also revealed that the category transition marker was the highest on female students. Furthermore, the factor in affecting of metadiscourse in gender was students' habit learning when the students learn at pondok pesantren. The researchers suggested to the other researchers that this study could give insight to the reader and interested in the same field of metadiscourse in different data. 


\section{REFERENCES}

Abdi, et al., (2010). The cooperative principle in discourse communities and genres: $\mathrm{A}$ framework for the use of metadiscourse.l, Journal of Pragmatics 42:1669-1679.

Abdi, R. (2011). Metadiscourse Strategies in Research Articles: A Study of the Differences across Subsectionsll. In The Journal of Teaching Language Skills 3 (1), Spring 2011, Ser. 62/4.

Allami. H, Mirshamsi, A. (2013). "Metadiscourse Markers in the Discussion/Conclusion Section of Persian and English Master's Theses", The Journal of Teaching Language Skills (JTLS) vol.5, No,3 .pp.

Al-Shujairi, Yasir, et.al. (2016). Role of Moves, Tenses, and Metadiscourse in the Abstract of an Acceptable Research Article. Mediterraneon Journal of Social Science. Vol. 7, No. 2: 379.
Hyland, Ken -Polly Tse. (2004). Metadiscourse in Academic Writing\|, Applied Linguistic, 25(2), 2004, pp.156-177.

Hyland, Ken. 2004. -Disciplinary interactions: metadiscourse in L2 postgraduate writing", Journal of Second Language Writing 13, 2004, 133-151.

Hyland, Ken. Metadiscourse: Exploring interaction in writing. London: Continiuum, 2005.

Mehrnaz, Tajalli \& Shokrpour. (2014) "An Investigation of Metadiscourse Markers in English Medical Text and Their Persian Translation Based on Hyland's Model",European Journal of English Language and Literature Studies, 2 (2), p.2. 